\title{
Effect of Patient Centered Care Application on Inpatient Outcomes in Rskdia Pertiwi and Rsia Ananda (Woman and Child Hospitals)
}

\author{
Zulkarnain Abubakar, Fridawaty Rivai*, Nurshanty A. Sapada \\ Department of Hospital Management, Faculty of Public Health, Hasanuddin University, Makassar, Indonesia
}

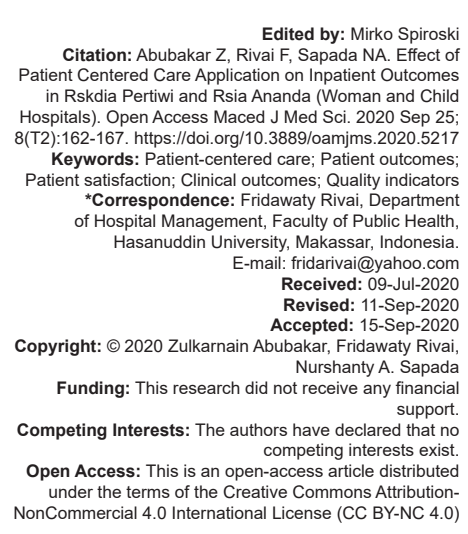

\section{Introduction}

The topic of the quality of service and patient safety has been one of the global issues and major focuses toward the health service, without exception in Indonesia. Hospitals are required to be able to guarantee the quality and safety of patients in providing services. In 2001, IOM in a report "Crossing The Quality Chasm: A New Health System for the $21^{\text {st }}$ Century" recommended a number of fundamentals needed in a health-care system known as Six Aims to Improve Healthcare, one of which is health-care institutions is required to able to provide services that are patientcentered [1].

Patient-centered care (PCC) is defined as care that is both respectful and responsive to the patient's preferences, needs, and values. In addition, this system ensures that patient values are used as guidelines in determining clinical decisions by health-care providers. PCC is one of the dimensions of high quality health services, where its application has been proven to improve the quality of overall health services [1]. PCC is a new paradigm in healthcare that places patients as the center of care. The new paradigm aims to get better health service outcomes, allocate appropriate resources, and improve patient and family satisfaction [2].

In Indonesia, the hospital's obligation to continuously improve and guarantee the quality of its services is regulated in Pasal 40 UU No. 44 Tahun 2009, which emphasized that hospitals must obtain accreditation periodically at least once every 3 years as part of efforts to improve the quality of services [3]. Accreditation carried out by the Hospital Accreditation Commission (KARS) requires hospitals to adopt and apply quality standards in accordance with the National Hospital Accreditation Standards (SNARS) $1^{\text {st }}$ edition.

The SNARS $1^{\text {st }}$ edition is designed with service standards that focus on patients with a risk management approach at the Hospital. This aims to not only influence the process, output, and outcomes but also to the application where all officers in the accreditation process are involved with the hope that a KARS-accredited hospital has the quality assurance, which will positively influence clinical outcomes and increase satisfaction patient in the long run [4].

In addition to the application of patient-centered standards, the application of PCC in accredited hospitals must be reviewed from the perception of patients as the main stakeholders in the health-care system [5], [6]. The 
application of PCC influences the patient's condition and perception of service quality which has an effect on increasing patient satisfaction, clinical outcomes, and hospital outcomes in ongoing process [7]. The results of the previous studies indicate that the application of PCC correlates to patient perceptions, satisfaction levels, and better service quality [8].

The application of PCC through patient involvement in their care can improve functional status, self-care behavior, and patient satisfaction. This process increases the knowledge and concern of patients for the conditions they experience, which makes patients actively involved in care, thereby increasing patient satisfaction and functional status [9]. Through PCC, nurses can better understand the problems experienced by patients individually. This makes patients feel more valued and served well, resulting in increased patient satisfaction [10].

Study showed that patient involvement in decision-making toward care was positively correlated with improvement in functional status, self-care behavior, and patient satisfaction [11]. This study evaluates patients' perceptions of the application of PCC in two different setting mother and child hospitals in Makassar, both in ownership, hospital class, and different levels of accreditation: RSKDIA Pertiwi which is a Class B mother and child hospital owned by the South Sulawesi provincial government and is accredited by SNARS $1^{\text {st }}$ edition at the level Utama, and RSIAAnanda which is a private Class $\mathrm{C}$ mother and child hospital and has been accredited by SNARS 1st edition at the level "Madya."

Although accredited, the level of inpatient satisfaction in both hospitals has not reached $\geq 90 \%$ according to the Hospital Minimum Service Standards according to the Health Ministry of Indonesia. In addition, there are no data on achieving clinical outcomes in both hospitals, where patient outcomes as a guarantee of service quality in both hospitals have not been achieved. This study aims to evaluate the application of PCC and its effect on patient outcomes in the form of patient satisfaction and clinical outcomes of inpatient at RSKDIA Pertiwi and RSIAAnanda, and to compare the application of PCC between both hospitals.

\section{Materials and Methods}

This study was conducted at the RSKDIA Pertiwi and RSIA Ananda from May to July 2019. The study was quantitative analytic with cross-sectional design approach. This study was designed to evaluate the effect of independent variables on two dependent variables: PCC on Patient Satisfaction and Clinical Outcomes of Inpatient in RSKDIA Pertiwi and RSIA Ananda.
The population in this study was all patients with post-emergency cesarean section who was hospitalized in RSKDIA Pertiwi and RSIA Ananda. The total sample was 92 patients who were determined proportionally: Twenty-one patients in RSKDIA Pertiwi and 71 patients in RSIA Ananda. The samples were collected with the following inclusion criteria: (1) In a conscious state; (2) admitted to the hospital with impartus status; (3) underwent emergency cesarean section surgery; (4) indication of emergency CS with prolonged $2^{\text {nd }}$ stage, fetal distress, oligohydramnios, induction failure, or cephalopelvic disproportion; (5) the patients did not experience severe preeclampsia, eclampsia, or HELLP syndrome; (6) the patient did not experience severe systemic diseases such as heart failure, kidney failure, liver failure; (7) inpatients $\geq 1$ day; and (8) performed outpatient control at least 7 days after hospitalization.

Data were collected using a measuring instrument in the form of a PCC application questionnaire, patient satisfaction questionnaire, and medical record data to review the clinical outcomes of the patient (inpatient) which consisted of length of stay (LOS), the presence or absence of phlebitis, the presence or absence of Hospital Acquired Infection, and presence or absence of surgical site infection at least 7 days after hospitalization.

The data were collected and analyzed using SPSS Version 22. Univariate analysis was performed to obtain the results of the characteristics of respondents and describe the achievements of each of the variables studied. Bivariate analysis of Mann-Whitney test was used to measure the comparison between the application of PCC in the RSKDIA Pertiwi and RSIA Ananda. Meanwhile, multivariate analysis of logistic regression tests was used to measure the effect of PCC application on patient satisfaction and clinical outcomes in RSKDIA Pertiwi, and linear regression tests were used to see the effect of PCC application on patient satisfaction and clinical outcomes at RSIA Ananda.

\section{Results}

Table 1 shows the characteristics of respondents in RSKDIA Pertiwi. At the onset, the majority of respondents were at the ideal age of pregnancy (18-35 years old) with $66.7 \%$, while most of them were housewives and unemployed with $57.1 \%$. In the next category, the most ethnic groups were from Makassar, which reached $57.1 \%$, while the highest level of education was high school or equivalent with $33.3 \%$ and postgraduate education of $4.8 \%$. In the category of religion, the majority of respondents are Muslim, reaching up to $81.8 \%$ and the rest are Christians. Furthermore, the majority of respondents utilize national insurance (BPJS Kesehatan) by $81 \%$ 
and others seek treatment at their own expense or use private insurances at $9.5 \%$, respectively. At the inpatient room, most respondents were at Class 3 with $42.9 \%$, and others were moderately distributed in each class moderately where the percentage of each class was VIP/VVIP with $19 \%$, Class 1 with $23.8 \%$, and Class 2 with $14.3 \%$. In the category of pregnancy history, $61.9 \%$ of respondents were multipara, and only $33.3 \%$ of patients had a history of cesarean section. Furthermore, $66.7 \%$ of patients were without cesarean section history, and $38.1 \%$ of patients were in the first pregnancy (primipara).

Table 1: Characteristics of respondents

\begin{tabular}{|c|c|c|c|c|}
\hline \multirow[t]{2}{*}{ Characteristic of respondents } & \multicolumn{2}{|c|}{ RSKDIA Pertiwi } & \multicolumn{2}{|c|}{ RSIAAnanda } \\
\hline & $(n=21)$ & $\%$ & $(n=71)$ & $\%$ \\
\hline \multicolumn{5}{|l|}{ Age } \\
\hline Ideal (18-35 years) & 14 & 66.7 & 58 & 81.7 \\
\hline At risk (> 35 years) & 7 & 33.3 & 13 & 18.3 \\
\hline \multicolumn{5}{|l|}{ Religion } \\
\hline Islam & 17 & 81.8 & 70 & 98.6 \\
\hline Christian & 4 & 19.2 & 1 & 1.4 \\
\hline \multicolumn{5}{|l|}{ Ethnicity } \\
\hline Makassar & 12 & 57.1 & 36 & 50.7 \\
\hline Bugis & 5 & 23.8 & 31 & 43.7 \\
\hline Toraja & 2 & 9.5 & 0 & 0 \\
\hline Mandar & 0 & 0 & 1 & 1.4 \\
\hline Others & 2 & 9.5 & 3 & 4.2 \\
\hline \multicolumn{5}{|l|}{ Occupation } \\
\hline Public Sector & 5 & 23.8 & 4 & 5.6 \\
\hline Private Sector & 2 & 9.5 & 13 & 18.3 \\
\hline Entrepreneur & 1 & 4.8 & 9 & 12.7 \\
\hline Professional & 0 & 0 & 3 & 4.2 \\
\hline Unemployed & 12 & 57.1 & 33 & 46.5 \\
\hline Others & 1 & 4.8 & 9 & 12.7 \\
\hline \multicolumn{5}{|l|}{ Monthly income } \\
\hline IDR $<1,000,000$ & 0 & 0 & 12 & 16.9 \\
\hline IDR $1,000,000-3,000,000$ & 2 & 9.5 & 14 & 19.7 \\
\hline IDR 3,000,000-5,000,000 & 7 & 33.3 & 12 & 16.9 \\
\hline IDR $>5,000,000$ & 0 & 0 & 3 & 4.2 \\
\hline No Income & 12 & 57.1 & 30 & 42.3 \\
\hline \multicolumn{5}{|l|}{ Payment method } \\
\hline Out of Pocket & 2 & 9.5 & 0 & 0 \\
\hline National Insurance (BPJS) & 17 & 81 & 69 & 97.2 \\
\hline Private insurances & 2 & 9.5 & 2 & 2.8 \\
\hline \multicolumn{5}{|l|}{ Education } \\
\hline Without formal school & 1 & 4.8 & 0 & 0 \\
\hline Primary & 2 & 9.5 & 7 & 9.9 \\
\hline Secondary & 2 & 9.5 & 4 & 5.6 \\
\hline High school & 7 & 33.3 & 19 & 26.8 \\
\hline Non-degree vocational diploma & 2 & 9.5 & 12 & 16.9 \\
\hline Bachelor degree & 6 & 28.6 & 25 & 35.2 \\
\hline Postgraduate degree & 1 & 4.8 & 4 & 5.6 \\
\hline \multicolumn{5}{|l|}{ Inpatient room } \\
\hline VIP/VVIP/Pavillun & 4 & 19 & 4 & 5.6 \\
\hline Class 1 & 5 & 23.8 & 18 & 24.4 \\
\hline Class 2 & 3 & 14.3 & 21 & 29.6 \\
\hline Class 3 & 9 & 42.9 & 28 & 39.4 \\
\hline \multicolumn{5}{|l|}{ Pregnancy history } \\
\hline Primipara & 8 & 38.1 & 30 & 42.3 \\
\hline Multipara & 13 & 61.9 & 41 & 57.7 \\
\hline \multicolumn{5}{|l|}{ History of CS } \\
\hline History of CS (-) & 14 & 66.7 & 27 & 38 \\
\hline History of CS (+) & 7 & 33.3 & 44 & 62 \\
\hline
\end{tabular}

At RSIA Ananda (Table 1), the majority of patients' age also ranged around the ideal age of pregnancy (18-35 years old) with $81.7 \%$, where $98.6 \%$ of respondents were Moslem and only $1.4 \%$ were Christians. About $50.7 \%$ came from Makassar, and $43.7 \%$ were Buginese, while the rest came from Mandar, and other ethnicities. In the category of occupation, most respondents were housewives or unemployed with $46.5 \%$, followed by private employees at $18.3 \%$. At the education level, most respondents were bachelor by $35.2 \%$ and the smallest percentage was at the master and junior/senior high school education level of $5.6 \%$. Table 1 also shows that the majority of respondents applied national insurance at $97.2 \%$ and only $2.8 \%$ with private insurance. Whereas, in the inpatient room, respondents at RSIA Ananda were quite distributed, which consisted of Class 3 with $39.4 \%$, Class 2 with $29.6 \%$, Class 1 with $24.4 \%$, and VVIP/VIP with $5.6 \%$. Furthermore, the majority of respondents at RSIA Ananda had a history of cesarean section surgery which reached $62 \%$. Whereas in the history of pregnancy, $57.7 \%$ of respondents were multipara patients and 42.3\% were primipara (first pregnancy).

The application of PCC is a patient's perception of care covering eight dimensions in the form of respect for patient preferences and value, information, education, and communication, coordination of care, emotional support, physical comfort, involvement of family, continuity and care, and access to care, as measured by the PCC application questionnaire. Table 2 shows that the application of PCC is good with the percentage of respondents in RSKDIA Pertiwi at $66.7 \%$ and in RSIA Ananda with $69 \%$.

Table 2: Frequency of variables

\begin{tabular}{|c|c|c|c|c|c|c|}
\hline \multirow[t]{2}{*}{ Variables } & \multicolumn{3}{|c|}{ RSKDIA Pertiwi } & \multicolumn{3}{|c|}{ RSIA Ananda } \\
\hline & $(n=21)$ & $\%$ & mean & $(n=71)$ & $\%$ & mean \\
\hline \multicolumn{7}{|c|}{ The application of PCC } \\
\hline Poor & 7 & 33.3 & 67.14 & 22 & 31 & 67.12 \\
\hline Good & 14 & 66.7 & & 49 & 69 & \\
\hline \multicolumn{7}{|c|}{ Patient satisfaction } \\
\hline Not satisfied & 15 & 71.4 & 66.62 & 35 & 49.3 & 72.75 \\
\hline Satisfied & 6 & 28.6 & & 36 & 50.7 & \\
\hline \multicolumn{7}{|l|}{ Clinical outcomes } \\
\hline Not achieved & 5 & 23.8 & 4 & 19 & 26.8 & 4 \\
\hline Achieved & 16 & 76.2 & & 52 & 73.2 & \\
\hline
\end{tabular}

According to the achievements of the PCC in each hospital (Table 3), it is clear that the dimension of Respect for Patient Preferences and Values was the highest according to respondents in RSKDIA Pertiwi at $90.5 \%$, while RSIA Ananda showed the highest percentage in the dimension of Information, Education, and Communication. Meanwhile, the dimension of Coordination of Care showed the lowest percentage of application in both hospitals.

The Mann-Whitney test for comparison of the application of PCC in RSKDIA Pertiwi and RSIA Ananda resulted in $p=0.492$, which meant there was no significant difference in the application of PCC in RSKDIA Pertiwi and RSIA Ananda. In addition, Table 1 shows that there was no significant difference in the application of PCC in the two hospitals, both from the achievement of the application and the mean values in the two hospitals.

The logistic regression test results of the effect of the application of PCC to patient satisfaction in RSKDIA Pertiwi showed $p=0.012$ (Table 4), and in the linear regression test, the application of PCC to patient satisfaction at RSIA Ananda showed $p=0.000$ (Table 5). According to these results, there was an affect of the application of PCC to patient satisfaction both in RSKDIA Pertiwi and RSIA Ananda.

Meanwhile, the results of the logistic regression test on the effect of the application of PCC on clinical outcomes in RSKDIA Pertiwi showed $p=0.718$ 
Table 3: Frequency of the dimensional of the PCC application

\begin{tabular}{|c|c|c|c|c|c|c|}
\hline \multirow[t]{2}{*}{ Dimensions } & \multicolumn{3}{|c|}{ RSKDIA Pertiwi } & \multicolumn{3}{|c|}{ RSIAAnanda } \\
\hline & $(n=21)$ & $(\%)$ & Mean & $(n=71)$ & $(\%)$ & Mean \\
\hline \multicolumn{7}{|c|}{ Respect for patient preferences and values } \\
\hline Poor & 2 & 9.5 & 8.90 & 20 & 28.2 & 8.52 \\
\hline Good & 19 & 90.5 & & 51 & 71.8 & \\
\hline \multicolumn{7}{|c|}{ Information, education and communication } \\
\hline Poor & 8 & 38.1 & 8.23 & 12 & 16.9 & 8.73 \\
\hline Good & 13 & 61.9 & & 59 & 83.1 & \\
\hline \multicolumn{7}{|c|}{ Coordination of care } \\
\hline Poor & 11 & 52.4 & 7.52 & 29 & 40.8 & 8.34 \\
\hline Good & 10 & 47.6 & & 42 & 59.2 & \\
\hline \multicolumn{7}{|c|}{ Emotional support } \\
\hline Poor & 11 & 52.4 & 8.28 & 28 & 39.4 & 8.41 \\
\hline Good & 10 & 47.6 & & 43 & 60.6 & \\
\hline \multicolumn{7}{|c|}{ Physical comfort } \\
\hline Poor & 8 & 38.1 & 8.24 & 25 & 35.2 & 8.34 \\
\hline Good & 13 & 61.9 & & 46 & 64.8 & \\
\hline \multicolumn{7}{|c|}{ Involvement of family } \\
\hline Poor & 3 & 14.3 & 8.76 & 22 & 31 & 8.49 \\
\hline Good & 18 & 85.7 & & 49 & 69 & \\
\hline \multicolumn{7}{|c|}{ Continuity and transition } \\
\hline Poor & 7 & 33.3 & 8.57 & 20 & 28.2 & 7.94 \\
\hline Good & 14 & 66.7 & & 51 & 71.8 & \\
\hline \multicolumn{7}{|l|}{ Access to care } \\
\hline Poor & 3 & 14.3 & 8.62 & 23 & 32.4 & 8.35 \\
\hline Good & 18 & 85.7 & & 48 & 67.6 & \\
\hline
\end{tabular}

(Table 4), while the results of the linear regression test on the effect of the application of PCC on clinical outcomes at RSIAAnanda showed $p=0.440$ (Table 5).

Table 4: Effect of PCC application on inpatient outcomes in RSKDIA Pertiwi

\begin{tabular}{lllllll}
\hline Variables & B & SE & Wald & Df & Sig. & Exp (B) \\
\hline Patient satisfaction & 2.079 & 1.133 & 5.714 & 1 & 0.017 & 0.067 \\
Clinical Outcomes & 0.383 & 1.060 & 0.130 & 1 & 0.718 & 1.467 \\
\hline
\end{tabular}

These findings indicate that there was no affect of the application of PCC on clinical outcomes both in RSKDIA Pertiwi and RSIA Ananda.

Table 5: Effect of PCC application on inpatient outcomes in RSIA Ananda

\begin{tabular}{llllll}
\hline Variables & $\mathrm{B}$ & $\mathrm{SE}$ & Beta & $\mathrm{t}$ & Sig. \\
\hline Patient satisfaction & 1.240 & 0.142 & 0.726 & 8.760 & 0.000 \\
Clinical Outcomes & -0.008 & 0.010 & 0.093 & -0.776 & 0.440 \\
\hline
\end{tabular}

\section{Discussion}

This study shows that the application of PCC in RSKDIA Pertiwi was relatively low. However, based on the frequency distribution of the PCC dimensions shows that the dimension of respect for patient preferences and values was very well implemented according to respondents, followed by dimension of involvement of family and access to care.

Likewise, the application of PCC inAnanda RSIA which is also relatively low, but if it is seen based on the frequency distribution of the PCC dimension it is known that the Information, Education and Communication dimensions have been well implemented according to respondents, followed by the dimension of respect for patient preferences and values, as well as continuity and transition. Respecting patient needs and their preferences, involvement of family, and access to information are the main elements in PCC [12]. It can be said that although the application of PCC in both hospitals is relatively low, but both hospitals have applied the basic principles of PCC application.

The high percentage of the dimension of respect for patient preferences and values in RSKDIA Pertiwi and dimension of Information, Education, and Communication in RSIA Ananda is due to the application of the accreditation standards that focus on patients, particularly related to Standard of Patient and Family Rights and Management of Communication and Education [4]. In RSIA Ananda is also supported by the role of doctors and nurses/midwives who are on average young at RSIA Ananda, with more friendly and communicative services to patients.

On the other hand, the dimension of coordination of care was the dimension with the lowest percentage of PCC according to respondents both in RSKDIA Pertiwi and RSIA Ananda. This shows that beside effective communication, the application of Coordination of Care also requires, collaboration, and standardization of processes to ensure that planning, coordination, and implementation of care can support and respond to each patient's needs and targets [4].

Statistical tests show the effect of the application of PCC to patient satisfaction both in RSKDIA Pertiwi and RSIA Ananda. Studies show that health-care delivery that is in accordance with patient needs and involving patients in their care is positively correlated with patient satisfaction [11]. In PCC, nurses better understand the problems experienced by patients individually. This makes patients feel more valued and served, thereby increasing patient satisfaction [10].

Involving patients in their care could increase the patient's knowledge and concern for the conditions they are experiencing, thus making patients more actively participated in their care, also increasing patient satisfaction [9]. Study showed a significant differences in satisfaction levels in the group receiving 
PCC compared to the control group, with the results of patients treated with PCC having a higher level of satisfaction [8], [13].

Studies showed that the application of PCC can improve patient experience of better healthcare quality, and create new value in services. The PCC concept designs healthcare processes to meet patient needs [14]. In general, satisfaction can be achieved when quality is able to meet expectations and needs [15]. The success of PCC can meet the needs and expectations of patients for quality of care so that makes patients more satisfied with the service.

Meanwhile, statistical tests show there is no affect of the application of PCC on clinical outcomes in RSKDIA Pertiwi or at RSIA Ananda. According to several studies, the application of PCC affect clinical outcomes associated with functional status improvement. This is due to PCC application which can increase patient compliance with doctor orders and therapies given [9], [11], [16].

The application of PCC also has a positive impact on clinical outcomes related to patients' selfcare behavior after discharge from hospital; patients treated with PCC are able to deal with symptoms and changes in conditions experienced in carrying out their daily activities [9], [11], [17]. In addition, the application of PCC is associated with a decrease of the anxiety level of patients during their care [18], [13].

Clinical outcomes associated with PCC in the previous studies are subjective, which assessed using the patient-reported outcome measure (PROMs) model after the patient discharge from the hospital. Whereas, clinical outcomes assessed in this study are clinical related and objective through the patient's medical record.

Study evaluated the similarity clinical outcomes with this research show that no significant correlation between PCC application with clinical outcomes, including length of stay (LOS), postoperative infection, falls and postoperative complications, in patients treated with PCC compared with those not treated with PCC [8].

The two different of clinical outcomes assessed in the previous studies indicated that clinical outcomes assessed in this study are influenced by clinical management related. This result is attributed by the monitoring of suboptimal implementation of clinical pathway after cesarean section surgery, especially related to post-operative length of stay [19], [20].

In addition, clinical outcomes assessed in both hospitals are associated by host-related risk factors, operation-related risk factors, and microbe-related risk factors [21], [22], [23], [24]. Therefore, if the infection control and prevention program in both hospitals are well implemented, it will affect the achievement of related-clinical outcomes.

Statistical test also shows that there was no significant difference in the application of PCC in
RSKDIA Pertiwi and RSIA Ananda. The successful application of PCC is associated with organizational culture that encourages staff to be more sensitive to the needs of patients in the hospital. In addition, it is needed effective leadership, adequate resourcing to support the model of care, staff capacity building, and active involvement of patients and families in all facet of the organization to achieve PCC [25].

It is intended that PCC can be implemented well and meet the concept. Patients, families, health workers, and health service leaders collaborate on policy making and program development, implementation and evaluation, both in research, facility design, professional education, and health service provision. The application of PCC does not correlate directly with the level of accreditation, type of ownership and hospital class, but this requires the role of all stakeholders and the commitment of health-care organizations in implementing PCC in accordance with predetermined concepts.

\section{Recommendation}

It is hoped that hospital management will improve the application of PCC by applying the concept of PCC holistically in providing services, particularly in the dimension of coordination of care. Effective communication is needed between service providers, patients and staff, as well as collaboration between professions and standardization processes to ensure that care plans, service coordination, and care applications support and respond to each patient's unique needs. This supports the fulfillment of patient expectations of service quality and increases overall patient outcomes.

\section{References}

1. Institute of Medicine. Crossing the Quality Chasm: A New Health System for the $21^{\text {st }}$ Century. Washington, DC: National Academy Press; 2001.

2. Frampton S, Guastello S, Brady C, Hale M, Horowitz S, Smith SB, Stone S. Patient-Centered Care Improvement Guide. London: Planetree and Picker Institute; 2008.

3. Kementrian Kesehatan RI. Undang-Undang Republik Indonesia Nomor 44 Tahun 2009 Tentang Rumah Sakit. Jakarta: Kementrian Kesehatan Republik Indonesia; 2009. https://doi. org/10.31219/osf.io/8e6an

4. Komisi Akreditasi Rumah Sakit. Standar Nasional Akreditas Rumah Sakit Edisi 1. Jakarta: Komisi Akreditasi Rumah Sakit 2017. https://doi.org/10.31227/osf.io/zfpjn

5. Wasson JH, Baker NJ. Balanced measures for patient-centered care. J Ambul Care Manag. 2009;32(1):44-55

PMid:19104293

6. Becker ER, Hockenberry JM, Bae J, Avgar AC, Liu SS Factors in patients' experience of hospital care: Evidence from California, 2009-2011. Patient Exp J. 2014;1(1):95-110. https:// 
doi.org/10.35680/2372-0247.1014

7. Rathert C, Wyrwich MD, Boren SA. Patient-centered care and outcomes: A systematic review of the literature. Med Care Res Rev. 2012;70(4):351-79. https://doi. org/10.1177/1077558712465774

PMid:23169897

8. Wolf DM, Lehman L, Quinlin R, Zullo T, Hoffman L. Effect of patient-centered care on patient satisfaction and quality of care. J Nurs Care Qual. 2008;23(4):316-21. https://doi. org/10.1097/01.ncq.0000336672.02725.a5 PMid:18806645

9. Sidani S. Effects of patient-centered care on patient outcomes: An evaluation. Res Theory Nurs Pract. 2008;22(1):24-37. https://doi.org/10.1891/1541-6577.22.1.24 PMid:18320906

10. Attree M. Patients and relatives experiences and perspectives of good and not so good quality care. J Adv Nurs. 2001;33:45666. https://doi.org/10.1046/j.1365-2648.2001.01689.x PMid:11251733

11. Poochikian-Sarkissian S, Sidani S, Ferguson M, Doran D. Examining the relationship between patient-centred care and outcomes. Can J Neurosci Nurs 2010;32(4):14-21. PMid:21268489

12. Riskiyah $\mathrm{R}$, Hariyanti $\mathrm{T}$, Juhariah $\mathrm{S}$. Pengalaman pasien rawat inap terhadap penerapan patient centered care di RS UMM. J Kedokteran Brawijaya. 2017;29(4):358-63. https://doi. org/10.21776/ub.jkb.2017.029.04.13

13. Sjarifudhin M, Rosa ME. Effectiveness of patient centered care to reduce anxiety level and improve satisfaction in patients undergoing cataract surgery. J Med Manajemen Rumah Sakit. 2018;7(3):188-95. https://doi.org/10.18196/jmmr.7372

14. Robb G, Seddon M. Quality improvement in New Zealand healthcare. Part 6: Keeping the patient front and centre to improve healthcare quality. N Z Med J. 2006;119(1242):2174. PMid:16998575

15. O'Malley JF. Ultimate Patient Satisfaction. New York, Europe: McGraw-Hill Education; 1997.

16. Constand MK, Macdermind JC, Law M, Below-Hass V. Patientcentered care and distal radius fracture outcomes: A prospective cohort study analysis. J Hand Ther. 2014;27(3):177-84. https:// doi.org/10.1016/j.jht.2014.04.001

\section{PMid:24874854}

17. Fredericks S, Lapum J, Hui G. Examining the effect of patientcentred care on outcomes. Br J Nurs. 2015;24(7):394-401. https://doi.org/10.12968/bjon.2015.24.7.394

PMid:25849237

18. Steward M, Brown JB, Donner A, McWhinney IR, Oates J, Weston W. The impact of patient-centered care on outcomes. J Fam Pract. 2000;49(9):796-804

PMid:11032203

19. Haninditya B, Andayani TM, Yasin NM. Analisis kepatuhan pelaksanaan clinical pathway seksio sesarea di sebuah rumah sakit swasta di Yogyakarta. J Manajemen Pelayanan Farm. 2019;9(1):38-45.

20. Fay EE, Hitti JE, Delgado CM, Savitsky LM, Mills EB, Slater JL. Laurent $A B$. An enhanced recovery after surgery pathway for cesarean delivery decreases hospital stay and cost. Am J Obstet Gynecol. 2019;221(4):349.e1-349.9. https://doi.org/10.1016/j. ajog.2019.06.041

PMid:31238038

21. Rubin RH. Surgical wound infection: Epidemiology, pathogenesis, diagnosis and management. BMC Infect Dis. 2006;6(171):1-2. https://doi.org/10.1186/1471-2334-6-171 PMid:17129369

22. Zuarez-Easton S, Zafran N, Garmi G, Salim R. Postcesarean wound infection: Prevalence, impact, prevention, and management challenges. Int J Womens Health. 2017;9:81-8. https://doi.org/10.2147/ijwh.s98876 PMid:28255256

23. Novelia S, Sae-Sia W, Songwathana P. Surgical site infection among women post cesarean section: An integrative review. Nurse Med J Nurs. 2017;7(1):46-55. https://doi.org/10.14710/ nmjn.v7i1.15127

24. Van-Otterloo L, Connelly C, Gould J, Abreo A, Elliott M. Mothers at risk: Factors affecting maternal postpartum length of stay. J Perinat Neonatal Nurs. 2018;32(4):303-14. https://doi. org/10.1097/jpn.0000000000000342 PMid:29939881

25. Gluyas H. Patient-centred care: Improving healthcare outcomes. Nurs Stand. 2015;30(4):50-9.

PMid:26394978 